\title{
The Impact of Type Script Cooperative Learning of the Mutual Cooperation Behavior on Economic Subjects
}

\section{Mokhammad Wahyudin¹, Leni Maryani², and Veri Aryanto Sopiansah³}

${ }^{1}$ STAIMA Cirebon, Jl. KH Masduqie Ali, Cirebon 45167, Indonesia

${ }^{2}$ Program of Economic Education Studies, Universitas Pasundan, Jl. Tamansari No. 6-8, Bandung 40116, Indonesia

${ }^{3}$ Graduate Students of Universitas Pendidikan Indonesia, Jl. Setiabudhi No. 229, Isola, Bandung 40154, Indonesia

\section{Abstract}

This study purposes to know the impact of type script cooperative learning of the mutual cooperation behavior on economic subject. Respondents from two classes were selected randomly at the west java provincial school in the country of Indonesia.

Corresponding Author: Mokhammad Wahyudin mokhammmad_wahyudin@ yahoo.com

Received: 7 August 2018 Accepted: 15 September 2018 Published: 22 October 2018

Publishing services provided by Knowledge E

(c) Mokhammad Wahyudin et al. This article is distributed under the terms of the commons Attribution License, which permits unrestricted use and redistribution provided that the original author and source are credited.

Selection and Peer-review under the responsibility of the ICE-BEES 2018 Conference Committee

\section{G OPEN ACCESS}

The study used a pre-test-post-test control group design that was used to compare the impact of cooperative type script and cooperative learning approaches commonly used by teachers in general to know three aspects of mutual cooperation or Gotong Royong (care, tolerance and contribution). The study found significant results in the type script cooperative learning model in improving the behavior of mutual cooperation (care, tolerance and contribution).

Keywords: type script cooperative learning model, the mutual cooperation behavior or Gotong Royong (care, tolerance and contribution), economic subject.

\section{Introduction}

Economic subject is taught at senior high schools in Indonesia starting from the tenth grade for all students and eleventh and twelfth for Social Sciences because in economics lessons majoring in Social Sciences is the main lesson so the ability must be obtained in the affective aspect of mutual cooperation behavior and to cultivate the economic activities that have the character of a nation and can be competitive in the future. Improving mutual cooperation behavior is needed because mutual cooperation is a character that must be possessed by all students who have studied economic subjects in order to compete and solve the low character of mutual help in every human being in the $21^{\text {st }}$ century. Indonesian identity must be improved for the participants 
educated through economic subjects so that students can do economic activities that are mutual help.

This is the basis of ideas and ideals of President Soekarno about his goal to realize a nation that makes mutual cooperation as its identity. As his mandate before the birth of the Indonesian nation. "If I squeeze the five into three, and the three into one, then I can be a single genuine Indonesian word "the mutual cooperation behavior". What a great mutual cooperation country! ", He said in front of the participants of BPUPKI, June 1st, 1945.

Character building is an effort of the realization and mandate of Pancasila from the opening of the 1945 Constitution. Character and it is a very important thing in everyday life as well as in society. According to Samari and Haryanto (2011:41), the character is interpreted as a way of thinking and behavior that is typical of each individual to live and work together well in the scope of family, community, nation, and country. According to Samari and Haryanto (2011:118), the mutual cooperation behavior is an action and attitude willing to cooperate with others to achieve common goals and mutual benefits. The intended purpose here is a goal for society.

The problems that occur today are actually caused by people who do not have good character. According to Walker (2003) among the discursive themes that permeate and legitimize the new era of growing beings are (a) the idea of objective human development as the ultimate goal of all education (Seligman 2011), (b) anti-instrumentalism, according to which quality certain human beings (especially virtues) are considered to be intrinsically constitutive - not merely conducive to - developing objectively (Annas 2011) and (c) the recognition that "education" and "development" are the normative basic concepts, so that all school-based work is inevitably full of value, not just some special classes in "morals", "citizenship" or "educational character" (Carr 2002) In short, good characters are worthy goals for themselves and should be the end of the education system.

The strategy of learning in the $21^{\text {st }}$ century according to Fisher, Frey and Revelation (2010) extend this nimble thought by showing that preparing students for the skills of $21^{s t}$ century skills and providing quality teaching and learning will require four phases of deliberate learning strategies that apply in schools, at home, and in the community and who support quality teaching and learning.

In order to improve the conduct of mutual corporation after learning the economics of recommended learning strategies, such as creating a learning environment, maximizing participation and training in group learning and facilitating learning activities (Busser and Walter 2013; [2]; Dörnyei 2001; [4]; Liu 2007; [9]; Revelation 2018). 
Cooperative learning of script type is one approach involving this cooperative learning strategy. Script type is defined as "instructional use of small groups so students work together to maximize themselves and learn from each other" ([5], 1: 5). They have two basic elements of positive interdependence and individual accountability $[5,8,13,14]$. "Positive interdependencies are interrelated among students together so that one cannot succeed unless all group members succeed" ([5], 1: 7). Their contributions to teamwork can be individually identified and assessed (McCafferty, Jacobs, and DaSilva Iddings 2006; [9, 11, 14]).

Characteristics of cooperative learning of type script that is not the same as traditional learning in the process of learning which is very passive and students can not develop the potential, and cooperative learning of type script has advantages of high school level compared with the traditional learning of the first free students in developing the potential that exists in itself more leverage and in this goal students are directed to be able to improve the attitude of mutual cooperation in the conduct of economic activities after learning economic subjects, the advantages that both students are able to apply mutual cooperation in both the school environment and social activities.

\subsection{Literature review}

\subsubsection{Improving the behavior of mutual cooperation on economic learning}

The theory of mutual cooperation implicated for economic subjects with the intention to improve the mutual cooperation behavior which serve as one of the bases of a learning goal and to be able to prepare students in a competitive atmosphere in the era of globalization in economic activity after studying economics.

Gotong royong comes from the word in Javanese, or at least has a Javanese nuance. The word gotong royong can be paired with the word pikul or lift, for example there is a big tree collapsed blocking the village road. The community worked it together to move the wood alongside the road. The villagers call it gotong royong or menggotong [18].

The word royong means together. In Javanese, the word saiyeg saeko proyo or one movement of one business alliance has a very close meaning to describe this word of royong. Like a white heron flying together, with its wings rhythmically, heading in one direction together, and people then call it with a holopis kuntul baris [18]. 
As for so gotong royong has the understanding that every individual in any condition must have the willingness to participate actively in adding value or positive to every object, problem or requirement of people around life, active participation can be in the form of material, financial aid physical, mental, spiritual, skill or skill, healthy donation or constructive counsel, be tolerance, cooperation and caring, and to pray only to God [18].

For those who still have not been able to do any of the above assistance alternatives, then they simply by silence and do nothing that can damage the situation and conditions prevailing at that time. Silence and not make the situation worse were already the implementation of the lowest mutual cooperation [18].

The perspective of mutual cooperation on the application of cooperative learning of type scripts model of focus on three purposes that is to improve the behavior of care, tolerance, contribution. In the cooperative learning of type scripts model "the cooperative objective structure makes a situation where the only way group members achieve their personal goals is if the group is successful" $([14], 16)$. Thus, the group members try to help one another, and more importantly they encourage each other to make the maximum effort. The award structure of the type script cooperative learning model is largely related to group awards, which means students are typically rated as a group, based on group performance or number of individuals.

\subsubsection{The cooperative learning of type script model in improving mutual cooperation behavior (care, tolerance and contribution)}

The principle of cooperative learning of type script model emphasizes the importance of creating supportive, caring, and positive behaviors in the environment, where students feel safe to engage in a highly motivated way to contribute to the group (Clement, Dörnyei and Noels 1994; [2]; Dörnyei 2001; [4, 8]; Noels et al., 2000). So, the this model is considered to be useful in facilitating students to learn economics in improving the behavior of mutual cooperation (care, tolerance and contribution)

\subsection{The purpose of the study}

The research in this journal is to investigate the impact of the application of the cooperative learning of type script model towards the improvement of mutual help (tolerance and contribution). And this journal focuses on determining the differences of 
the impact of the model in particular and compares the conventional learning model in one school in Cirebon, West Java Indonesia.

\section{Research Method}

This research was conducted in a school in Cirebon, West Java, Indonesia. In the world of education, especially in learning, the implementation of research is not always possible to do random subject selection, because the subject naturally has formed in one whole group, such as groups of students in one class. In such circumstances the rules of pure experimental research cannot be fully satisfied, because the control of the variables related to the subject of research cannot be done completely, so the research should be done by using quasi experimental method and survey conducted to determine the level of effectiveness of the cooperative learning of type script model to behave mutual cooperation.

The population in this study is all students of class XI Social Sciences (IPS) is 76 students. The reason for choosing class XI students in this study is because students of class XI have been assumed to have sufficient knowledge, ready to solve questions that can be answered more logically, not too disturbed by educational activities such as preparation and implementation of national examination. Sampling technique that will be used in this research is purposive sampling technique. Purposive sampling is also known as sampling consideration. Purposive sampling is a sampling technique used by researchers if researchers have certain considerations in sampling or sample determination for a particular purpose. The sample in this research is experiment class, comparative class and control class. Where one class of experiment is student of class XI IPS 1 with amount 38, and one control class that is students of class XI IPS 2 with number of student 38 in academic year 2017.

The data collection in this research will use written test economic subjects. The test is held in the form of pretest and posttest. Pretest was administered before treatment in order to know the scores of initial learning outcomes, while posttest was administered after treatment in order to find out the increase in learning outcomes after treatment in the experimental group, comparison group and control group to obtain the gain, i.e. the difference between the pretest score and posttest score. Problem given is a matter of economic subjects class XI on economic subjects. And data collection is done through a survey given to the students to know the level of impact from cooperative learning of type script model in mutual cooperation behavior. 


\subsection{Research procedure}

This study was conducted for three months; with students studying economics lessons per week is 4 hours of subjects in one week. Thus the research is done through experimental research by dividing control class and experiment class that is pre-test posttest quasi experiment. The purpose of the research and the technique of applying the cooperative learning of type script model are used to know how to improve the behavior of mutual cooperation (gotong royong) of students after studying economic subjects by using it.

\subsection{Intervention procedure}

This research is divided into two groups of students those are experimental class group by applying cooperative learning of type script model and control group with learning model commonly used by teacher. The research design used is Control Group Design. In analyzing the data, each individual's pretest score is subtracted from its posttest score, allowing for change analysis. The design is preceded by pretest and then treated then done with posttest.

\section{Results}

Based on the result of validity test, it is known that all items in this research are valid, because t-table is bigger than t-table $>0,468$ by using significant level $\alpha=0,05$. So a valid test is feasible to be used as a measuring tool for further research. While testing the reliability of the problem aims to see the provisions of the matter. To calculate the reliability of a multiple choice test, this study uses Spearman Brown formula, the value of reliability obtained from the calculation of 0.843 . These results indicate the problem in a very high category and can be used in research. The next step the researchers do the normality test where the variable $X$ and $Y$ variable shows the significance value 200 * so it can be concluded that the variables that have been tested normal distribution.

The analysis of the item covers the distinguishing power and the degree of difficulty of the problem, while the result of (1) the differentiating power of the problem is the ability of a grain problem in distinguishing the students who have high ability with the students who have low ability Based on the analysis it is known that 1 item of question is sufficiently categorized and 19 the matter is categorized well. A good and sufficient question can be used for research. (2) problem level, Based on the analysis result, it is 
known that from 20 items of matter, 14 items are categorized as moderate difficulty, 3 problems are categorized difficulty level and 3 problems are categorized difficult difficulty level (the calculation is in appendix). It shows the distribution of the difficulty level of a good question. Therefore, it can be concluded that the matter deserves to be given as a matter of pretest and posttest.

\subsection{Economic competence in each class}

In this study, analysis of research results conducted on pretest and posttest results obtained at the time of the study. Pretest data is data obtained by testing the research instrument (test) conducted before treatment is applied, whereas posttest is data obtained by testing the research instrument (test) after treatment is done. Here are the results of research in experimental class and control class.

TABle 1: Average Pretest and Posttest Value of Experiment Class.

Pretest
$\begin{aligned} & \text { Posttest } \\ & 53,11\end{aligned}$
$\begin{aligned} & \text { Source: the calculation results of Microsoft Office Excel } 2010, \text { customized }\end{aligned}$

Based on the data above, before treatment is applied, students have average result of learning result equal to 53,11 , while after treatment is held, student learning result increase to 85,81 .

TABle 2: Average Pretest Value, Posttest and Gain Experiment Class.

\begin{tabular}{|c|c|c|}
\hline $\begin{array}{l}\text { Average pretest } \\
\text { value }\end{array}$ & $\begin{array}{c}\text { Average posttest } \\
\text { value }\end{array}$ & Gain \\
\hline 53,11 & 85,81 & 32,7 \\
\hline
\end{tabular}

From the change of pretest and posttest result table, it can be seen that the change shows the result of pretest and posttest, and an increase of the average of the result of student learning in the experimental class.

TABLE 3: Average Value of Pretest and Posttest Results Control Class.

$\begin{array}{lc}\text { Pretest } & \text { Posttest } \\ 52,43 & 72,43 \\ \text { Source: calculation results of Microsoft Office Excel } 2010\end{array}$

From the data shown above, the pretest and posttest score of students in the control class has an average of learning outcomes during pretest of 52.43 , whereas at posttest, student learning outcomes increased to 72.43 . 
TABle 4: Average Pretest Value, Posttest and Gain Control Class.

\begin{tabular}{l|c|c|}
\hline $\begin{array}{l}\text { Average pretest value } \\
\text { s2,43 }\end{array}$ & $\begin{array}{c}\text { Average posttest } \\
\text { value }\end{array}$ & Gain \\
\hline $\begin{array}{l}72,43 \\
\text { source: calculation results of Microsoft Office Excel 2010, customized }\end{array}$ \\
\hline
\end{tabular}

From the pretest and posttest changes table, it can be seen that the changes indicate the result of pretest and posttest and an increase in the average value of student learning outcomes in the control class.

\subsection{Differences in gain values in the experimental class and control class}

From the descriptive data of the experimental class and control class showed that there were an increase in posttest time. Posttest in the experimental class is obtained with an average value of 85.81 , whereas in the control class is obtained posttest with an average of 72.43 . Based on these data shows that cooperative learning of type script model is effective to cultivate mutual attitude (care, tolerance and contribution/ gotong royong).

The posttest graph of the result in the experimental class and the control class show as follows:

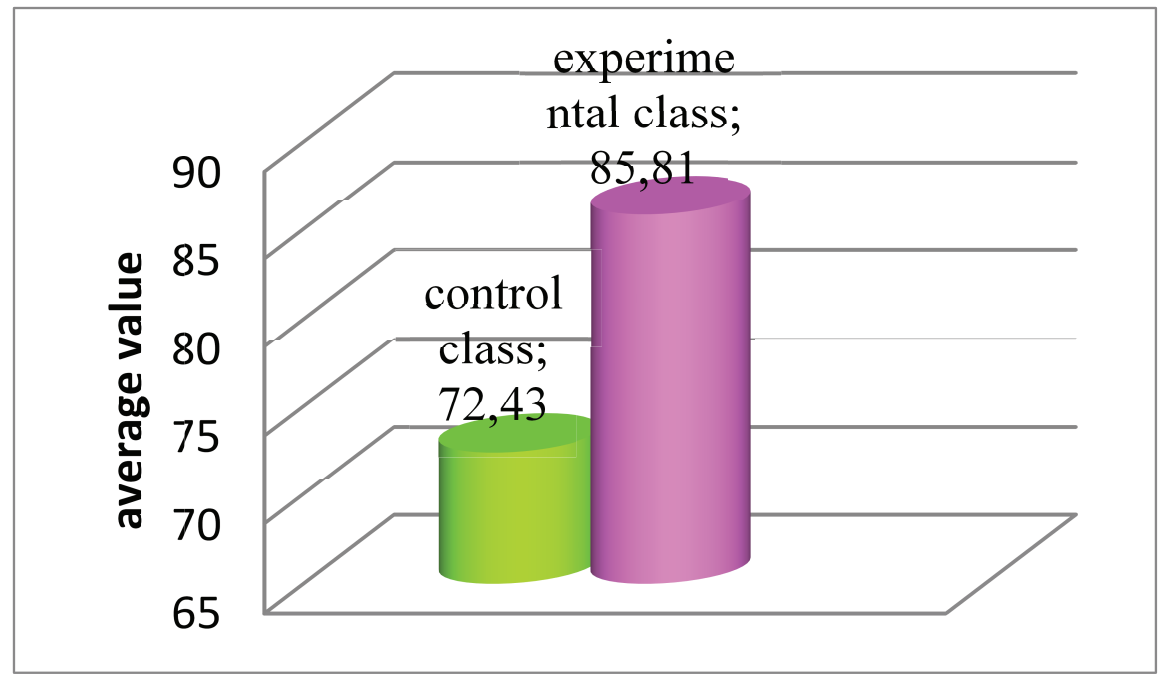

Figure 1: Comparison of the mean posttest grade of the experimental class and the control class.

From the graph shows that the average posttest value in the experimental class is higher than the average value in the class, the control. The average comparison of values between the experimental and control classes is 13.38 . 


\subsection{Influence between variables}

TABLE 5: The Impact of Type Script Cooperative Learning of the care, tolerance and contribution.

\begin{tabular}{|c|c|c|c|c|c|c|c|c|c|}
\hline \multicolumn{10}{|c|}{ Coefficients $^{a}$} \\
\hline \multicolumn{2}{|c|}{ Model } & \multicolumn{2}{|c|}{$\begin{array}{l}\text { Unstandardized } \\
\text { Coefficients }\end{array}$} & \multirow{2}{*}{$\begin{array}{c}\text { Standardized } \\
\text { Coefficients } \\
\text { Beta }\end{array}$} & \multirow[t]{2}{*}{$\mathrm{T}$} & \multirow[t]{2}{*}{ Sig. } & \multicolumn{3}{|c|}{ Correlations } \\
\hline & & B & $\begin{array}{l}\text { Std. } \\
\text { Error }\end{array}$ & & & & $\begin{array}{l}\text { Zero- } \\
\text { order }\end{array}$ & Partial & Part \\
\hline \multirow[t]{4}{*}{1} & (Constant) & 70.483 & 4.839 & & 9.762 & .000 & & & \\
\hline & Care & .290 & .053 & .411 & 5.424 & .000 & .445 & .408 & .397 \\
\hline & Tolerance & .440 & .041 & .551 & 10.682 & .000 & .586 & .533 & .508 \\
\hline & Contribution & .280 & .055 & .397 & 5.135 & .000 & .445 & .391 & .376 \\
\hline
\end{tabular}

From the table above shows that after learning by using cooperative learning of type script model on economic subjects to mutual cooperation /Gotong Royong (care, tolerance and contribution) showed that all variables have significant result or have impact to application of type script cooperative learning model in mutual cooperation /gotong royong (care, tolerance and contribution).

\section{Discussion and Conclusions}

Based on the results of the research obtained from the average posttest 85.81 for the experimental class and 72.43 for the control class, showed that the increase in student learning outcomes in the experimental class using cooperative learning of type script model is better than the control class that uses the learning commonly used by teachers, this is in line with the purpose of the study. This shows that cooperative learning of type script model can be an alternative in economic learning especially to grow or improve the attitude of mutual assistance (care, tolerance and contribution). And based on survey result that is done that data from coefficients table shows significance value for questionnaire of variable of care, tolerance and contribution and show that existence of impact after study by using this model in improving mutual cooperation behavior/ gotong royong (care, tolerance and contribution)

The biggest impact after using this model is increasing the attitude of care tolerance and contribution to fellow students both in class and in school environment. And the positive value of the application of this model to facilitate the learning atmosphere of students who feel supported and guided, where students feel happy to learn. 
In cooperative learning of type script model emphasize on the learning process that can impact to familiarize students to be care, tolerance and giving contribution to fellow students or peers, by implementing this model, they can be mutual care, tolerance and giving contribution in the process of learning activities in the classroom and the impact of the implementation of cooperative learning of type script model is that students realize that the importance of personality enhancement to students about the personality so that the scope of the school among students can be personality care, tolerance and contribution.

In this study shows that the learning outcomes of the different cooperative learning of type script models and conventional learning model are usually done by teachers differences in learning outcomes present that the value of the application of cooperative learning model is higher than the conventional model is usually done in school. Furthermore, the results of pre-test and post-test show an increase in learning outcomes for the cooperative learning of type script model and there is also an increase in learning outcomes for conventional learning is usually done in the classroom.

In conclusion, this study demonstrates that cooperative learning of type script model has an important role to be used in economic teaching in Indonesia because the result this model is better than conventional learning in improving mutual attitude/gotong royong (care, tolerance and contribution). However, there are some limitations in this study that quasi experimental research is limited to half a semester involving only 76 students although in the whole learning application of economic learning subjects were conducted fully for three years and to know the full impact of learning is done then ideally research was conducted over three years and involved longer experimental periods and more students in order to confirm the findings of the research results.

Recommendations for future research are the application of learning model can use a mixed-design learning model including quantitative data (e.g. tests or surveys) and qualitative data (e.g. from interviews with students or teachers) in a single study. This approach to research is well-regarded to understand the broad research regulations (i.e. from quantitative data) and steep (i.e. from quantitative data), and to explore the quantitative data obtained from interviews with students, some of which can improve the increasing impact of possible outcomes of responses in the study.

\section{References}

[1] Armansyah. "Pengaruh Penerapan Model Pembelajaran Cooperative Script Terhadap Hasil Belajar Siswa Pada Mata Effect of Application Cooperative Learning 
Model on the Script of Student Learning in Biology Class Subject Viii 4 Smp Negeri 1 Makassar." Jurnal Nalar Pendidikan 2.1 (2014): 66-71.

[2] Dörnyei, Z. 1997. "Psychological Processes in Cooperative Language Learning: Group Dynamics. " The Modern Language Journal 81: 482-493

[3] https://hasrilpmp.wordpress.com/2009/01/27/implementasi-perilaku-gotongroyong-dalam-kehidupan-masyarakat-perkotaan-bulukumba/. Diakses: 26 Desember 2017

[4] Jacobs, GM, and CC Goh. 2007. Cooperative Learning in the Language Classroo.Singapore: SEAMEO Regional Language Center.

[5] Johnson, DW, RT Johnson, and EJ Holubec. 1998. Cooperation in the Classroom. 7th ed. Edina, MN: Interaction Books.

[6] Joyce, B., Weil, M., \& Calhoun, E (2016). Models of Teaching (nine Edition). New Jersey: Prentice-Hall, Inc.

[7] Joyce, B., Weill, M. (2000) Models of Teaching. Boston: Allyn and BaconKohelberg, L., (1976), The Cognitive Developmental Approach to Moral Education. Berkly: Cutchan Publ. Co.

[8] Kagan, S., and M. Kagan. 2009. Kagan Cooperative Learning. San Clemente, CA: Kagan Publishing.

[9] Ning, H. 2011. "Adapting Cooperative Learning in Tertiary ELT." ELT Journal 65: 60-70.

[10] Ning, H., and G. Hornby. 2010. "Effectiveness of Cooperative Learning in Teaching English to Chinese Tertiary Learners." Effective Education 2: 99-116.

[11] Ning, H. 2013. "The Impact of Cooperative Learning on the English as a Foreign Language Tertiary Learners' Social Skills. " Social Behavior and Personality 41: 557568.

[12] Pengertian gotong royong. (online) http://manfaatpengetahuan. blogspot.com/ 2014/01/ pengertian-gotong-royong.html. Diakses: 26 Desember 2017

[13] Richards, J., and TS Rodgers. 2001. Approaches and Methods in Language Teaching. 2nd ed. Cambridge: Cambridge University Press.

[14] Slavin, RE 1995. Cooperative Learning: Theory, Research, and Practice. 2nd ed. Needham Heights, MA: Allyn and Bacon.

[15] Slavin, RE 2000. Educational Psychology: Theory and Practice. 6th ed. Boston, MA: Allyn and Bacon.

[16] Smith, K. A. 1989. "The Craft of Teaching Cooperative Learning: An Active Learning Strategy." In Proceeding of Frontiers in Education Conference, Binghamton, NY, 188193. 
[17] Smith, K. A. 1995. "Cooperative Learning: Effective Teamwork for Engineering Classrooms." In Proceedings of Frontiers in Education Conference, Atlanta, GA, vol. 1, 2b5.13-2b5.18.

[18] ("Atau Menggotong (Abdillah, 2011). Kata Royong Dapat Dipadankan Dengan Bersama-Sama. Dalam Bahasa Jawa Kata")"Atau Menggotong (Abdillah, 2011). Kata Royong Dapat Dipadankan Dengan Bersama-Sama. Dalam Bahasa Jawa Kata." (2011): 9-41. Print. 